\title{
Evaluation of Some Biochemical Properties of the Juice of Two Varieties of Sweet Potato Grown in the North of Côte d'Ivoire During a Fermentation Process
}

\author{
MOROH Jean-Luc Aboya ${ }^{1}$, KOKORA Aya Philomène ${ }^{1}$, KARAMOKO Detto ${ }^{1}$, KAMATE Moustapha ${ }^{1}$, OUATTARA Kiyinma ${ }^{1}$, \\ YAO Ange Olivier Parfait ${ }^{1}$, COULIBALY Adama ${ }^{1,2}$ \\ ${ }^{1}$ Biochemistry and Genetics Department, Biological Sciences Training and Research Unit of Peleforo Gon Coulibaly university. \\ BP 1328 Korhogo, Côte d'Ivoire \\ ${ }^{2}$ Biochemical Pharmacodynamics Laboratory, Biosciences Biological Sciences Training and Research Unit of Félix Houphouët- \\ Boigny university. 22 BP 582 Abidjan 22 Côte d'Ivoire
}

\begin{abstract}
Like cassava flour for making "attiéké" (cassava semolina), the sweet potato tuber, after grinding followed by pressing, produces flour and juice. The present work aims to enhance this juice from the sweet potato by a fermentation which leads to an alcoholic drink. The process consists of five steps including juice extraction, gelation, enzymatic hydrolysis by millet malt, pasteurization and fermentation. We have followed the evolution of some chemical and biochemical parameter at each step of the process. The results indicate that enzymatic hydrolysis with millet malt increases the reducing sugar level by 10 times which was $0.074 \mathrm{~g} / \mathrm{ml} \pm 0.013$ and $0.041 \mathrm{mg} / \mathrm{ml} \pm 0.011$ respectively for white-fleshed sweet potato and yellow flesh after extraction. However, the process drops the vitamin $\mathrm{C}$ level from $0.1 \mathrm{mg} / \mathrm{ml} \pm 0.013$ of white-fleshed potato juice and $0.05 \mathrm{mg} / \mathrm{ml} \pm \mathbf{0 . 0 0 2}$ of yellow-fleshed potato juice to $6.610-3 \mathrm{mg} / \mathrm{ml} \pm 1.9 .10^{-3}$ and $5.9 .10^{-3} \mathrm{mg} /$ $\mathrm{ml} \pm \mathbf{0 . 8 . 1 0 - 3}$ in the same order. The optimal production of alcohol during fermentation is obtained with a concentration of $40 \mathrm{mg} / \mathrm{L}$ of yeast to reach an alcohol level of $5.56 \% \pm 0.1$ and $4.60 \% \pm 0.1$ respectively for the potatoes. sweet with yellow flesh and white flesh after 6 hours.
\end{abstract}

Keywords:- Sweet Potato, Fermentation, Vitamin C, Reducing Sugar, Saccharomyces Cerevisiae.

\section{INTRODUCTION}

The sweet potato, Ipomoea batatas (L.), belonging to the convolvulaceae family, is a plant cultivated in the tropics and subtropics for the tubers it produces [1]. It is the sixth largest crop in the world after rice, wheat, potatoes, maize and cassava with more than 133 million tons produced each year [2]. This strong production concerns the countries of the tropical and subtropical zones in Asia, America and Africa. It is a crop in which $56 \%$ of this production comes from developing countries [3]. In view of the agronomic characteristics it possesses, namely its good producibility, good adaptability with a relatively short cultivation cycle and high nutritional value, the sweet potato is also presented as an important crop for food security [4-6].
In addition, according to the work of Owori [7], the sweet potato constitutes an important source of carbohydrates $(96 \%)$, in the form of simple sugars and dietary fibers, which play an important role in energy deficiencies. In addition to being a carbohydrate source like tubers, sweet potato particularly contains ascorbic acid (vitamin C), vitamin B and A, iron, zinc and calcium [8].

In Côte d'Ivoire, it is cultivated in all regions and constitutes a relatively large proportion of the food consumed and also a source of income. National production, which was 47,914 tons in 2013 , is mainly made up of white and yellow fleshed sweet potatoes. The cultivation of the orange-fleshed sweet potato rich in $\beta$-carotene is hampered by the scarcity of varieties with this characteristic [9]. However, varieties with orange and yellow flesh are richer in available organic beta carotene (provitamin A), an important asset for the nutritional improvement of the population, in particular infants and young children.

The sweet potato, despite its good agronomic and nutritional characteristics, remains a marginal crop. It is characterized by low average productivity growth estimated at 46,403 tons in 2005 to 47,914 tons in 2013. Its exploitation is limited to its consumption in the form of frying and porridge with a virtual absence of industrial processing.

Today, in Côte d'Ivoire, one of the avenues for its transformation is undoubtedly the exploitation of its flour. The latter has been the subject of several studies by different authors. These studies are generally focused on the technofunctional properties, biochemical characters and nutritional values of sweet potato flour [10-14]. The grinding followed by the pressing of the fresh tubers makes it possible to obtain on the one hand a residue which can be reduced to flour. On the other hand, the juice of the sweet potato can be a second product. This prospective study therefore aims to enhance the latter (the juice of the sweet potato) through its transformation into an alcoholic or non-alcoholic drink, while retaining the nutrients of interest contained in this tuber. 


\section{MATERIAL AND METHODS}

\section{$>$ Sampling and extraction of sweet potato juice}

The biological material is composed of two varieties of sweet potato cultivated in the region of Korhogo, in the north of Côte d'Ivoire. It is a variety of sweet potato with red skin and yellow flesh and a variety with beige skin and white flesh. These two varieties were harvested in an orchard in Torkaha, a village located $15 \mathrm{~km}$ from the town of Korhogo.

After sampling, the two varieties of sweet potatoes were washed under a jet of water to remove any soil in order to reduce any contamination from the soil. After peeling, which consisted of removing the epidermis from the tuber using a knife, the tubers were cut into small pieces to facilitate grinding.

Then $1400 \mathrm{~g}$ of sweet potato tuber was crushed using a mechanical grinder. The pulps of the two varieties were put in different tissues for pressing and finally to collect the juices in jars.

These different juices, carefully stored at $5^{\circ} \mathrm{C}$, protected from light, were then centrifuged at $3000 \mathrm{rpm}$ for 15 minutes at $5^{\circ} \mathrm{C}$. The supernatants were collected and also stored at $5^{\circ} \mathrm{C}$ protected from light.

\section{Enzymatic Hydrolysis of Starch by Millet Malt}

The enzymatic hydrolysis of starch in sweet potato juice was performed with amylases from sprouted millet. Malting involved soaking unshelled millet in water for 07 hours. At the end of this time, the seeds were removed and left for germination for 4 days. Then the germinated millet grains were ground into a fine powder [15]. Then $10 \mathrm{~g}$ of germinated millet powder are added to $50 \mathrm{ml}$ of distilled water with magnetic stirring. After filtering the mixture through Wattman filter paper, the filtrate was stored for the remainder of the process.

Then, two jars containing $250 \mathrm{ml}$ for each juice were brought to a water bath for 10 minutes to obtain gelation. After cooling the various gelled juices, $10 \mathrm{ml}$ of malt filtrate were added and then the whole was incubated at $60^{\circ} \mathrm{C}$. for one hour.

\section{Sweet potato juice sterilization}

In order to determine the best pasteurization scale, in a series of ten (10) sealed bottles, numbered 1 to 10 , we introduced $30 \mathrm{ml}$ of sweet potato juice. These vials were treated at $90^{\circ} \mathrm{C}$, respectively for a period of 1 minute to 10 minutes. At the end of these respective times, the vials and their contents are suddenly cooled in an ice bath.

After this treatment, $1 \mathrm{ml}$ of the sweet potato juice contained in each vial was inoculated into $9 \mathrm{ml}$ of nutrient broth. After incubation at $37^{\circ} \mathrm{C}$ for 24 hours, monitoring of the microbial density that survived the treatment was done by reading the optical density of the cultures at $600 \mathrm{~nm}$ [16]. The optical density values obtained allowed us to calculate the percentage of survival of the microorganisms compared to the control without treatment which represents $100 \%$ of survival [17]. The best sterilization time was chosen for the pasteurization of all the sweet potato juice.

\section{Fermentation}

The fermentation of the juice of the sweet potato was done with Saccharomyces cereviciae. In order to find a suitable dosage of the yeast used in our juices, we took a few samples on which we made a variation in the yeast concentration, then we determined the alcohol level in the different samples.

To do this, in two series of five Erlenmeyer flasks numbered 1 to 5 , we introduced $50 \mathrm{ml}$ of hydrolyzed and pasteurized sweet potato juice. Then, we inoculated $0.5 \mathrm{mg}$, $1 \mathrm{mg}, 2 \mathrm{mg}, 4 \mathrm{mg}$ and $8 \mathrm{mg}$ respectively of brewer's yeast (Saccharomyces cereviciae), hence initial microbial concentrations of $10 \mathrm{mg} / \mathrm{L}, 20 \mathrm{mg} / \mathrm{L}, 40 \mathrm{mg} / \mathrm{L}, 80 \mathrm{mg} / \mathrm{L}$ and $160 \mathrm{mg} / \mathrm{L}$. These tubes are then incubated at room temperature for 5 hours. The fermented juice obtained in these different tubes is used for biochemical tests. The determination of the ethanol formed was carried out using an alcohol refractometer

\section{Vitamin C dosage}

Vitamin C was determined using the iodometric method $[18,19]$. It allowed us to assess the level of vitamin $\mathrm{C}$ remaining in the juice at each stage of the process, including the various pasteurization scales.

In an Erlenmeyer flask containing $10 \mathrm{ml}$ of sweet potato juice, are added $1 \mathrm{ml}$ of a $1 \mathrm{M}$ sulfuric acid solution and then 2 drops of a $1 \%$ starch solution. The vitamin $\mathrm{C}$ contained in this juice is dosed with an iodine solution (Lugol) concentrated at $4.7310^{-5} \mathrm{M}$ using a burette until the juice reaches its blue color endpoint. The volume of Lugol's solution used for the dosage makes it possible to determine the concentration of vitamin $\mathrm{C}$ in this juice.

\section{$>p H$ and Titratable acidity}

In $10 \mathrm{ml}$ of sweet potato juice contained in an Erlenmeyer flask, a few drops of phenolphthalein are added. Then, the sweet potato juice solution is dosed using a burette with $0.1 \mathrm{~N} \mathrm{NaOH}$ solution until an orange color is obtained. The amount of soda solution used for the dosage makes it possible to determine the titratable acidity of the juice according to the formula below

$$
\begin{gathered}
\quad \% A T=\frac{\mathrm{VNaOH} * \mathrm{NNaOH} * 0.09 * 100}{\text { V sample }} \\
\mathrm{V}_{\mathrm{NaOH}}: \mathrm{NaOH} \text { volume } \\
\mathrm{N}_{\mathrm{NaOH}}: \mathrm{NaOH} \text { normality }(0.1 \mathrm{~N}) \\
\mathrm{V}_{\text {sample }}: \text { Sample volume }
\end{gathered}
$$

The $\mathrm{pH}$ was measured directly using a $\mathrm{pH}$ meter fitted with an electrode previously calibrated using two buffer solutions. The sample to be analyzed was first brought to a temperature of around $20^{\circ} \mathrm{C}$. We then took 10 $\mathrm{ml}$ of the sweet potato juice sample in a jar and then the $\mathrm{pH}$ was measured by dipping the electrode into the juice. The 
value displayed on the screen of the $\mathrm{pH}$ meter represents the $\mathrm{pH}$ of the juice

\section{Reducing sugar dosage}

In a beaker containing $9 \mathrm{ml}$ of distilled water, $1 \mathrm{ml}$ of the juice of each variety of sweet potato was added and the whole was then homogenized. Next, $0.3 \mathrm{ml}$ of DNS (3.5 Dinitrosalycilic Acid) were added to the solution and then the mixture is brought to a boiling water bath for $5 \mathrm{~min}$. After cooling the resulting solution, $4 \mathrm{ml}$ of distilled water was added thereto. The optical density of the solution obtained at $540 \mathrm{~nm}$ against a blank is used to determine the concentration of reducing sugar from a calibration line established with the assay under the same conditions of different concentrations of glucose [20]

\section{RESULTS}

\section{Extraction}

The extraction of $1400 \mathrm{~g}$ of sweet potato from both varieties provided us with $450 \mathrm{ml}$ of yellow sweet potato juice and $330 \mathrm{ml}$ of white sweet potato juice. The extraction yield is estimated at $0.321 \mathrm{ml}$ per gram of yellow-fleshed sweet potato versus $0.236 \mathrm{ml}$ per gram for the white fleshed tuber.

\section{Sterilization of the juice of the two varieties of potato}

The pasteurization scale here consists in identifying the optimum processing time for the juice of the two varieties of sweet potato treated at $90^{\circ} \mathrm{C}$ to eliminate the microorganisms present in this juice. This processing time for sterilizing the juice of the two varieties of sweet potato was evaluated at 7 minutes for the juice of the white-fleshed sweet potato and 8 minutes for that of the yellow-fleshed sweet potato. Treatment at $90^{\circ} \mathrm{C}$ during these determined times eliminates the microorganisms present in both types of juice as shown in Figure 1

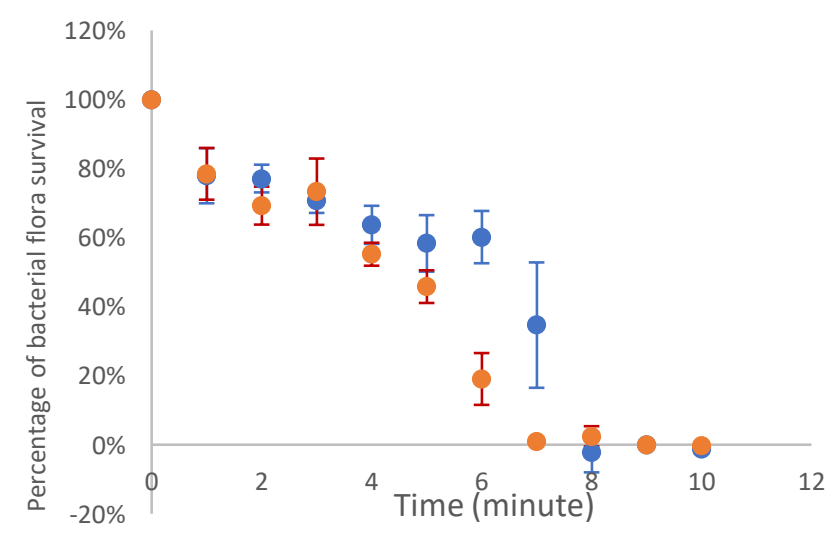

- yellow-fleshed sweet potato white-fleshed sweet potato

Fig 1:- Percentage of bacterial flora survival as a function of treatment time at $90^{\circ} \mathrm{C}$

\section{Alcoholic fermentation}

Figure 2 shows the different values of the alcohol content depending on the initial yeast concentration in the different tubes. The alcohol level produced changes with the initial concentration and tends to stabilize from an initial yeast concentration of $40 \mathrm{mg} / \mathrm{L}$ regardless of the variety of sweet potato used.

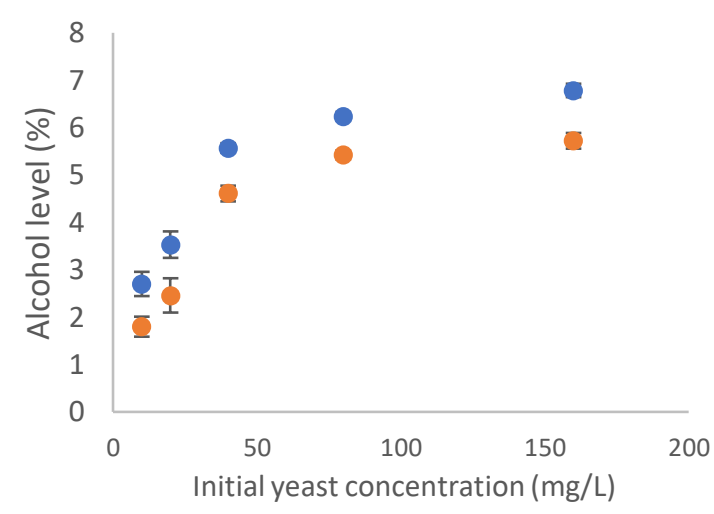

- white-fleshed sweet potato yellow-fleshed sweet potato

Fig 2:- level of alcohol produced according to the concentration of the ferment

Variation of some chemical and biochemical parameters during the sweet potato juice processing process

- Vitamin C

The two varieties of sweet potato contain vitamin $\mathrm{C}$. Their initial concentration is $0.1 \mathrm{mg} / \mathrm{ml} \pm 0.013$ of juice from white-fleshed potatoes and $0.05 \mathrm{mg} / \mathrm{ml} \pm 0.002$ of juice from yellow-fleshed potatoes. These different vitamin C concentrations correspond to contents of $3.21 \mathrm{mg}$ of vitamin $\mathrm{C}$ per $100 \mathrm{~g}$ of yellow-fleshed sweet potato tuber and $1.18 \mathrm{mg}$ of vitamin $\mathrm{C}$ per $100 \mathrm{~g}$ of the white-fleshed variety.

The evolution of the concentration of vitamin $\mathrm{C}$ during the process of processing the juice of the two varieties of sweet potato is shown in Figure 3.

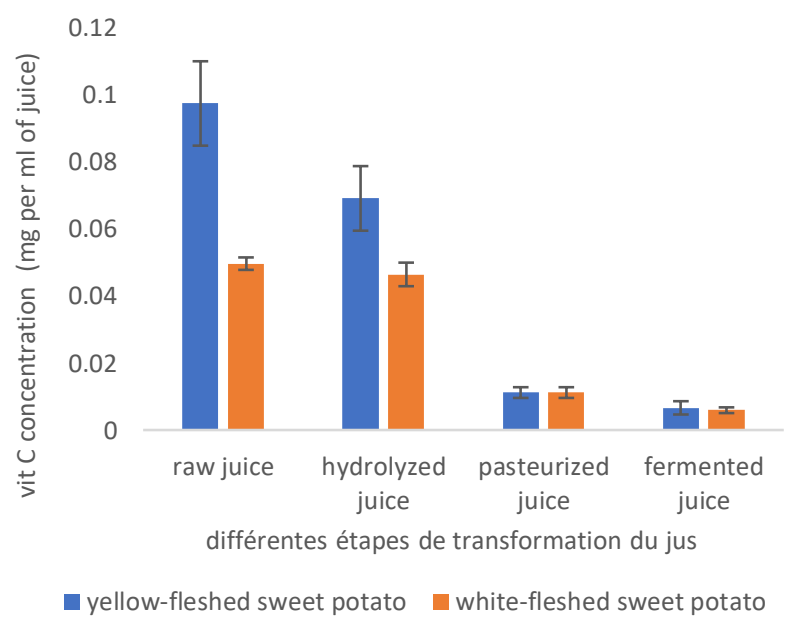

Fig 3:- Variation of vitamin $\mathrm{C}$ during processing of sweet potato juice

\section{- Reducing sugars}

Figure 4 shows the values of the concentrations of reducing sugars in the juice of the two varieties of potato throughout the processing process. We observe a reducing sugar concentration of $0.074 \mathrm{~g} / \mathrm{ml} \pm 0.013$ and $0.041 \mathrm{mg} / \mathrm{ml}$ 
\pm 0.011 respectively for the juices of the yellow-fleshed and white-fleshed sweet potatoes. After the enzymatic hydrolysis process, these values change to $0.857 \mathrm{~g} / \mathrm{ml} \pm$ 0.042 and $0.375 \mathrm{mg} / \mathrm{ml} \pm 0.052$ in the same order. They reach a concentration of $0.0144 \mathrm{mg} / \mathrm{ml} \pm 0.01$ and 0.0119 $\mathrm{mg} / \mathrm{ml} \pm 0.01$ after alcoholic fermentation, always in the same order.

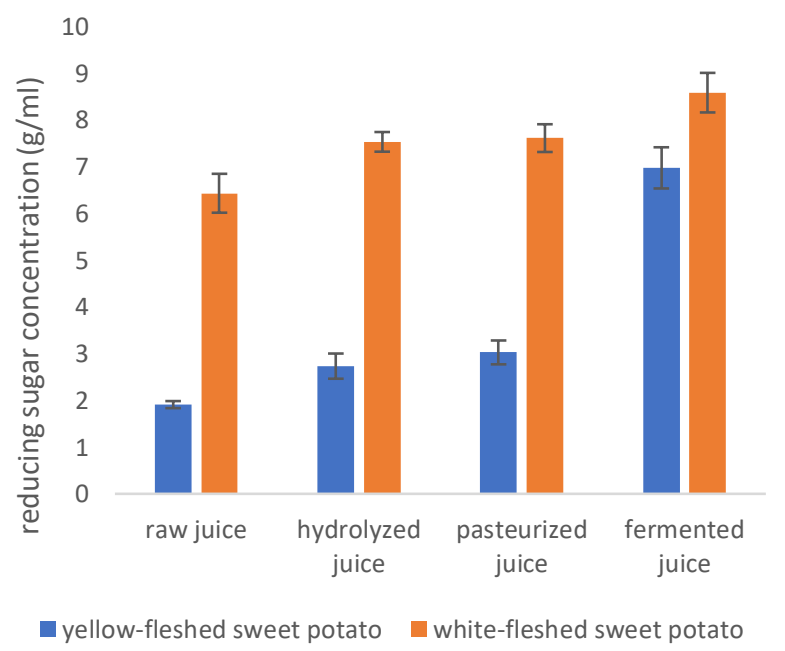

Fig 4:- Evolution of the reducing sugar level during processing

\section{- Titratable acidity and $\mathrm{pH}$}

Figure 5 shows the evolution of the titratable acidity of the juice of the two varieties of sweet potato throughout their processing. There is a growth in titratable acidity throughout the process, from juice extraction to fermentation. With $\mathrm{pH}$, Figure 6 exhibit a decrease in $\mathrm{pH}$ throughout the process. It goes from 6.05 to 5.43 for the yellow-fleshed sweet potato and from 6.04 to 5.34 for the white-fleshed sweet potato.

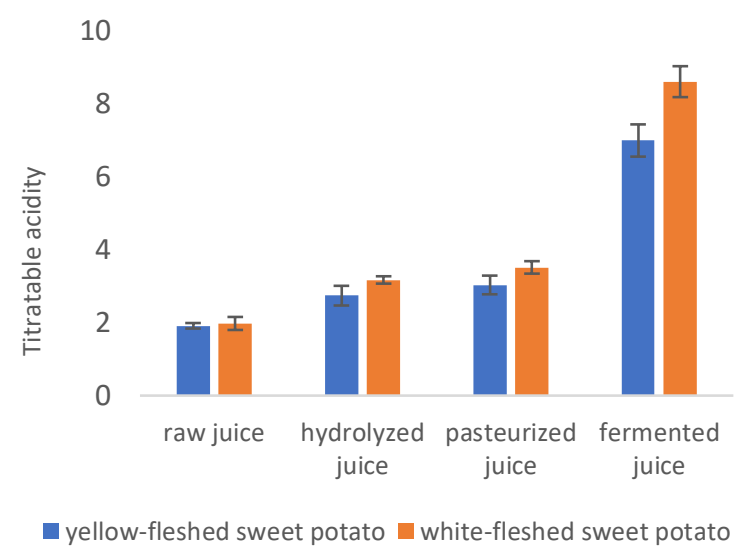

Fig 5:- Evolution of titratable acidity during processing

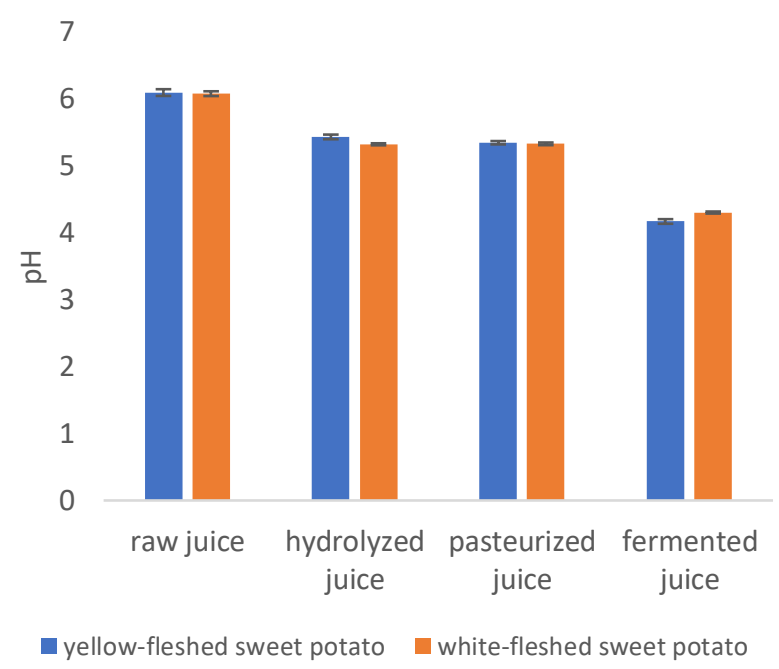

Fig 6:- Evolution of $\mathrm{pH}$ during transformation

\section{DISCUSSION}

Sweet potato flour is a product that enhances the value of this tuber by transforming it into various finished products (porridge, ready meals, bakery and pastry, etc.). The physical processes used to obtain it from the sweet potato tubers also allow us to have juice. The latter product also contains nutrients such as vitamins A, B and C, minerals, carbohydrates and proteins contained in the tuber of the sweet potato. This study aims to exploit and promote this juice through its transformation into a fermented drink.

After grinding and pressing the pulp of the tuber of the two varieties of sweet potato, there is a juice extraction yield of $32.1 \mathrm{ml}$ per $100 \mathrm{~g}$ of yellow-fleshed sweet potato and 23.6 $\mathrm{ml}$ of juice. per $100 \mathrm{~g}$ of white-fleshed sweet potato. These results reveal to us significantly that the tuber of the yellowfleshed sweet potato variety would be juicier and contain less dry matter than that of the white-fleshed sweet potato. This variation in the dry matter rate in the different varieties of sweet potato has also been observed by some authors $[9$, $21,22]$

The process of transforming these juices into a fermented drink begins with enzymatic hydrolysis of the starch in the juice into glucose, then pasteurization followed by alcoholic fermentation.

Enzymatic hydrolysis involves the action of amylases in sprouted millet on the starch contained in the juice of two different varieties of sweet potato. Sterilization, on the other hand, was done with several pasteurization scales in order to identify the one that eliminates microorganisms while affecting the quality of the juice as little as possible. The juice of two varieties of sweet potato was treated at $90^{\circ} \mathrm{C}$ for times varying from 1 minute to 10 minutes. The results reveal a treatment of $90^{\circ} \mathrm{C}$ for a time of 7 minutes and 8 minutes for respectively the juice of the sweet potato with white flesh and with yellow flesh is necessary to reduce more than $99 \%$ of microorganism present. 
The juice of the two varieties of sweet potato was fermented with Saccharomyces cerevisiae brewer's yeast at different concentrations for 6 hours of incubation at room temperature. The results obtained show us an increasing production of alcohol in the same order as the concentration of the juice in ferment. It is noted that for a concentration of $1.5 \mathrm{~g} / \mathrm{ml}$ of ferment, an alcohol level of $4.5 \%$ is obtained after 6 hours of incubation with the juice obtained from the yellow-fleshed sweet potato and $5.59 \%$ with that of whitefleshed sweet potatoes. These results are similar to those obtained by Mounir [16] with 5 varieties of sweet potatoes.

The juice of these varieties of sweet potato has a sweet flavor with reducing sugar levels of $0.07 \mathrm{~g} / \mathrm{ml} \pm 0.013$ and $0.04 \mathrm{mg} / \mathrm{ml} \pm 0.01$ for the respective juices of the yellowfleshed sweet potato and white-fleshed sweet potato. Knowing that these juices were obtained with $1400 \mathrm{~g}$ of tuber, these values bring us to a respective reducing sugar level of $2.25 \mathrm{~g}$ per $100 \mathrm{~g}$ of yellow-fleshed sweet potato and 0.94 per $100 \mathrm{~g}$ of fleshed sweet potato. white. These values are close to those obtained by Kourouma [20] on ten sweet potato cultivars. Furthermore, it is noted that these values are lower than those obtained by Hou [23]. According to the same author, roasting the tubers increases the reducing sugar level. Enzymatic hydrolysis with amylases from sprouted millet significantly increased the reducing sugar level in the juice of the two varieties of sweet potato by about ten times. This reducing sugar level is not significantly affected by heat treatment during pasteurization. This reducing sugar in the juice is used by the ferment for the production of ethanol which causes a decrease in the level of reducing sugar in the various juices after fermentation. The concentration of reducing sugar is also a factor influencing the production of ethanol during alcoholic fermentation $[16,24]$.

The initial vitamin $\mathrm{C}$ level is estimated at $0.1 \mathrm{mg} / \mathrm{ml} \pm$ 0.01 and $0.05 \mathrm{mg} / \mathrm{ml} \pm 0.001$ respectively for yellow-fleshed and white-fleshed sweet potatoes. These values bring us back to values of $3.21 \mathrm{mg}$ of vitamin $\mathrm{C}$ per $100 \mathrm{~g}$ of yellowfleshed sweet potato tuber and $1.18 \mathrm{mg}$ of vitamin $\mathrm{C}$ per $100 \mathrm{~g}$ of the white-fleshed variety. These results are consistent with those published by U.S. Department of Agriculture (USDA) [25] which indicate that the level of ascorbic acid in sweet potato varieties varies from 0.3 to 4.9 $\mathrm{mg}$ per $100 \mathrm{~g}$ of tuber. The enzymatic hydrolysis reaction significantly affects this vitamin C content. During this hydrolysis, vitamin $\mathrm{C}$ could be exposed to possible oxidants generated by this process. Although the temperature has little effect on vitamin $C$ [26], we notice that the heat treatment of the juice through its pasteurization significantly reduces its concentration in the various juices. It could still be the action of oxidants during hydrolysis.

The $\mathrm{pH}$ values obtained with the different varieties of sweet potato are $6.09 \pm 0.05$ and $6.08 \pm 0.03$ for the yellowfleshed and white-fleshed sweet potato juices respectively. These values are above that obtained by Ouédraogo [24] in the residues of a potato variety. These values can be influenced by the degree of fermentation of the sample in question, which could in part justify this difference. The variation in $\mathrm{pH}$ and titratable acidity throughout the process could be a consequence of the fermentation reactions in the different juices. The evolution of $\mathrm{pH}$ is closely related to that of titratable acidity, the two being inversely proportional [27]. There is thus a significant decrease in the $\mathrm{pH}$ (growth of titratable acidity) of the juice extraction in the enzymatic hydrolysis process.

However, these values did not change significantly before and after pasteurization. The pasteurization having eliminated the microorganisms present in the juice, prevents its fermentation. This would explain these results. Fermentation of the juice with Saccharomyces cerevisiae after 6 hours allows the juices to have $\mathrm{pH}$ of $4.17 \pm 0.03$ and $4.30 \pm 0.01$ for the yellow-fleshed and white-fleshed sweet potatoes, respectively. These values are almost identical with that obtained by Ourega [28] who observed $\mathrm{pH}$ of 4.45 and 4.59 after fermentation of plantain juice.

\section{CONCLUSION}

Alcoholic beverages are made from foods used around the world. The present work was based on the production of alcoholic beverage made from the different varieties of sweet potato grown in the Korhogo region. The juice extracted after crushing was put into fermentation. This study allowed the development of the production diagram and the determination of some physico-chemical parameters of the alcoholic drink. The physicochemical analyzes revealed that the alcoholic drink has a $\mathrm{pH}$ of 5.29, an acidity rate of 8.1 and an alcohol degree ranging from $2.80 \%$ to $4.33 \%$ depending on the concentration of the yeast. It also emerges from this work that the transformation process implemented considerably reduces the level of vitamin C.

\section{REFERENCES}

[1]. Djinet, A.I., S. Koussao, and B. Ngaryam, Production et commercialisation de la patate douce [Ipomoea batatas (L.) Lam. dans les environs de Bongor. Journal of Applied Biosciences, Vol. 137(2019): p. 1398513996, 2019

[2]. Tong, C., W. Ru, L. Wu, W. Wu, and J. Bao, Fine structure and relationships with functional properties of pigmented sweet potato starches. Food Chemistry, Vol. 311: p. 126011, 2020

[3]. Scott, G.J., M. Rosegrant, C. Ringler, and L. Maldonado, Global Projections for Potato and Sweetpotato to the yeaur 2020. Potato and sweetpotato, Vol.: p. 357-364, 2020

[4]. Roullier, C. "Aux origines de la diversité de la patate douce (Ipomoea batatas) : une enquête phylogéographique en Amérique tropicale (aire d'origine) et en Océanie (aire d'introduction)",Biologie des populations Doctorat, Ecole doctorale Systèmes Intégrés en Biologie, Agronomie, Géosciences, Hydroscie, Université de Montpellier 2, 2012.

[5]. Kodjo, G., A. Atsou, O. Komi, T. Koffi, A.-M. M-L, E.K. Djidjolé, K.A. Dzifa, M. Aziadekey, S. Akpavi, A. Essozima, and P. Rassimwaï, Régénération in vitro par organogenèse directe de pousses à partir de boutures de trois cultivars de patate douce (Ipomoea 
batatas) originaire $d u$ Togo. European Scientific Journal, Vol. 10(27): p. 276-291, 2014

[6]. Doussoh, A.M., J.S. Dangou, S.S. Houedjissin, A.K. Assogba, and C. Ahanihanzo, Analyse des connaissances endogènes et des déterminants de la production de la patate douce [Ipomoea batatas (L.)], une culture à haute valeur socioculturelle et économique au Bénin. International Journal of Biological and Chemical Sciences Vol. 10(6): p. 2596-2616, 2016

[7]. Owori, C., B. Lemaga, R.O.M. Mwanga, A. Namutebi, and R. Kapinga, Sweetpotato Recipe Book : Sweetpotato Processed Products from Eastern and Central Africa Kampala- Uganda. ASARECA, PRAPACE, CIP and NARO. 2007

[8]. Sanoussi, A.F., A. Dansi, H. Ahissou, A. Adebowale, L.O. Sanni, A. Orobiyi, M. Dansi, P. Azokpota, and A. Sanni, Possibilities of sweet potato [Ipomoea batatas (L.) Lam] value chain upgrading as revealed by physico-chemical composition of ten elites landraces of Benin. African Journal of Biotechnology, Vol. 15(13): p. 481- 489, 2016

[9]. Dibi, K.E.B., B.S. Essis, B. N'zué, A.M. Kouakou, G.P. Zohouri, A.B. Assouan, and T.J.O.A. Van Mourik, Participatory selection of orange-fleshed sweetpotato varieties in north and north-east Côte d'Ivoire. Vol. 2(1): p. 83-90, 2017

[10]. Badila, C., M. Diatewa, G.G. Ellaly, and D. Nguyen, Mise au point d'un procédé de fabrication des farines de banane plantain et de tubercules de patate douce. I : évaluation des caractéristiques chimiques des farines. Annale des sciences et techniques, Vol. 10(4), 2009

[11]. Koala, M., A. Hema, R.S. Eloi Palé, F. Dupire, C. Françoise, A. Sérémé, M. Nacro, Y. Chapleur, and D. Laurain-Mattar, Farine de la Patate Douce à Chair Orange : caractérisation des caroténoüdes et conservation Journal de la Société Ouest-Africaine de Chimie, Vol. 38: p. 42-49, 2014

[12]. Kana, J.R., D. Matkréo, K. Kreman, M. Diarra, K.H. Mube, T.R. Ngouana, and A. Teguia, Effet $d u$ taux d'incorporation de la farine de patate douce crue dans l'aliment sur les performances de croissance du poulet de chair Journal of Applied Biosciences, Vol. 91(2015): p. 8539-8546, 2015

[13]. Ndangui, C.B. "Production and characterisation of sweet potato (Ipomoea batatas Lam) flours: optimisation of the technology of breadmaking", Université de Lorraine, 2015.

[14]. Njoya, A.M., C.W. Nain, S.D. Mendi, and H. Imele, Evaluation sensorielle du couscous de farine de manioc (Manihot esculenta, Crantz) substituée par celle de patate douce (Ipomoea patatas, Lam). Tropicultura, Vol. 34(2): p. 180-185, 2016

[15]. Sidibé, S., A. Coulibaly, D. Koné, and M. Doumbia, Amélioration de la viscosité et de la densité énergétique des bouillies infantiles préparées à partir de farines composées a base de riz, de niébé, de soja et d'arachide. Agronomie Africaine Sp. , Vol. 29(1): p. 53-61, 2017
[16]. Mounir, M., M. Belgrire, S. Lahnaoui, A. Hamouda, P. Thonart, F. Delvigne, and M.I. Alaoui, Maîtrise de la fermentation alcoolique sous stress éthanolique, thermique et osmotique de la souche Saccharomyces cerevisiae YSDN1 en vue de la préparation du vinaigre de fruits. Rev. Mar. Sci. Agron. Vét. , Vol. 4(2): p. 8695, 2016

[17]. Moroh, J.-L.A., C. Bahi, K. Dje, Y.G. Loukou, and F. Guédé-Guina, Etude de l'activité antibactérienne de l'extrait acétatique (EAC) de Morinda morindoides (Baker) milne-redheat (rubiaceae) sur la croissance in-vitro des souches d'Escherichia coli. Bulletin de la société royale des sciences de Liège, Vol. 77: p. 44 61, 2008

[18]. Dima, F., C. Vizireanu, and D. Istrati, Préserver la qualité des petit pois vert surgélés pendant l'entreposage. St. Cerc. St. CICBIA Vol. 13(2): p. 211 $-222,2012$

[19]. Ahodegnon, D.K., M. Gnansounou, R.G.S. Bogninou, E.R. Kanfon, B. Chabi, P.C. Agbangnan Dossa, E.A. Anago, E. Ahoussi, V. Wotto, and D.C.K. Sohounhloue, Biochemical profile and antioxidant activity of Parkia biglobosa and Tamarindus indica fruits acclimated in Benin. Vol. 6(11): p. 702-711, 2018

[20]. Kourouma, V., T.-H. Mu, M. Zhang, and H.-N. Sun, Comparative study on chemical composition, polyphenols, flavonoids, carotenoids and antioxidant activities of various cultivars of sweet potato. International Journal of Food Science \& Technology, Vol. 55(1): p. 369-378, 2020

[21]. Feruzi, M., P. Phemba, M. Ngongo, V. Hagenimana, and N.B. Lutaladio, Évaluation Post Récolte de Six Génotypes de Patate Douce Sélectionnés à l'Est du Congo. African Crop Science Journal, Vol. 9(1): p. 33-39, 2001

[22]. Djinet, A.I., R. Nana, M.M. Nguinambaye, B. Badiel, B. Konaté, L. Nanema, and Z. Tamini, Etude du comportement de dix (10) variétés de patate douce cultivées à Bongor en saison sèche International Journal of Innovation and Applied Studies, Vol. 17(4): p. $1384-13902016$

[23]. Hou, F., T. Mu, M. Ma, and C. Blecker, Optimization of processing technology using response surface methodology and physicochemical properties of roasted sweet potato. Food Chemistry, Vol. 278: p. 136-143, 2019

[24]. Ouédraogo, N., A. Savadogo, M.K. Somda, C. Zongo, and A.S. Traore, Essai de production de protéines d'organismes unicellulaires par des souches de levures à partir de résidus de tubercules de patate douce et d'igname. BASE, Vol. 16(4): p. 463-467, 2012

[25]. U.S. Department of Agriculture (USDA). Sweet potato, raw, unprepared (Includes foods for USDA's Food Distribution Program). 2019 [cited 2020 06/05/2020]; Available from: https://fdc.nal.usda.gov/fdc-app.html\#/fooddetails/168482/nutrients. 
[26]. Blasco, R., M.J. Esteve, A. Frígola, and M. Rodrigo, Ascorbic acid degradation kinetics in mushrooms in a high-temperature short-time process controlled by a thermoresistometer. LWT - Food Science and Technology, Vol. 37(2): p. 171-175, 2004

[27]. Fagla, A. "Production du vin de maïs à partir du surnageant fermenté issu de la production de «ogui» et contrôle de qualité",Master Ingenieur, Ecole Polytechnique d'Abomey - Calavi, Université d'Abomey - Calavi, 2016.

[28]. Ourega, D.A., L.B. Koffi, K.F. N'Guessan, G.J. Nemlin, K. Tano, and K.M. Dje, Caractéristiques physico-chimiques des bières de plantain produites à partir de rebuts de plantain de différentes variétés de Côte d'Ivoire (Orishele, French 2 et Corne 1)[Physicochemical characteristics of plantain beers produced from waste plantain varieties of Côte d'Ivoire (Orishele, French Horn 2 and 1)]. International Journal of Innovation Applied Studies, Vol. 10(2): p. 666-677, 2015 